\title{
(2) OPEN ACCESS \\ Nautilus-assisted coil embolization for a complex AcomA wide-necked aneurysm in the setting of acute subarachnoid hemorrhage
}

\author{
Alexander Sirakov, ${ }^{1}$ Svetozar Matanov, ${ }^{1}$ Pervinder Bhogal, ${ }^{2}$ Stanimir Sirakov (i) ${ }^{1}$
}

\begin{abstract}
${ }^{1}$ Radiology Department, University Hospital St Ivan Rilski, Sofia, Sofiâ, Bulgaria Interventional neuroradiology, Royal London Hospital, London, UK
\end{abstract}

Correspondence to Dr Stanimir Sirakov, Radiology Department, University Hospital St Ivan Rilski, Sofia 1431 , Bulgaria; ssirakov@bsunivers. com

Received 18 April 2021 Accepted 11 May 2021

Check for updates

(C) Author(s) (or their employer(s)) 2021. Re-use permitted under CC BY-NC. No commercial re-use. See rights and permissions. Published by BMJ.

To cite: Sirakov A

Matanov S, Bhogal P, et al. J Neurolntervent Surg Epub ahead of print: [please include Day Month Year] doi:10.1136/

neurintsurg-2021-017670

\section{ABSTRACT}

Numerous devices and sophisticated strategies have been developed to further increase the number of aneurysms amenable to endovascular treatment. ${ }^{1-4}$ Despite the superfluity of available neurovascular armamentarium, wide-necked bifurcation aneurysms can still pose a significant technical challenge to the treating clinician..$^{5-7}$ Neck bridging is a conceptually new approach, which provides increased occlusion rates with lower recurrence and complications rates. ${ }^{8-10}$ The Nautilus (EndoStream Medical) is an intrasaccular bridging device intended to assist in coil embolization of wide-necked cerebral aneurysms. This CE-marked device, available in various sizes, consists of flexible-layers, and is a nitinol-based, detachable implant. The device is delivered through a standard microcatheter with a minimal $0.0165 "$ inner diameter and is fully radiopaque and completely resheathable.

Owing to its unique 'tornado' like shape the device entirely reconstructs the aneurysmal neck, which facilitates the following coil embolization. In this video 1 , we demonstrate the use of Nautilus - assisted coil embolization for a complex anterior communicating artery (AcomA) wide-necked aneurysm in the setting of acute subarachnoid hemorrhage.

Contributors AS and SM: wrote the manuscript and edited the video. PB: carried out a critical review. SS: performed the case and final review.

Funding The authors have not declared a specific grant for this research from any funding agency in the public, commercial or not-for-profit sectors.

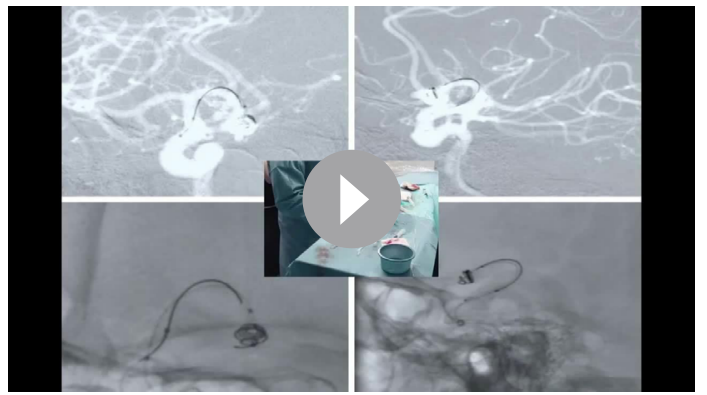

Video 1
Competing interests None declared.

Patient consent for publication Not required.

Ethics approval All procedures performed in the studies involving human participants were in accordance with the ethical standards of the institutional and/or national research committee and with the 1964 Helsinki Declaration and its later amendments or comparable ethical standards.

Provenance and peer review Not commissioned; externally peer reviewed.

Open access This is an open access article distributed in accordance with the Creative Commons Attribution Non Commercial (CC BY-NC 4.0) license, which permits others to distribute, remix, adapt, build upon this work non-commercially, and license their derivative works on different terms, provided the original work is properly cited, appropriate credit is given, any changes made indicated, and the use is non-commercial. See: http:// creativecommons.org/licenses/by-nc/4.0/.

ORCID iD

Stanimir Sirakov http://orcid.org/0000-0001-6034-5340

\section{REFERENCES}

1 Aydin K, Stracke P, Berdikhojayev M, et al. Safety, efficacy, and durability of stent plus balloon-assisted coiling for the treatment of wide-necked intracranial bifurcation aneurysms. Neurosurgery 2021;88:1028-37.

2 Akhunbay-Fudge CY, Deniz K, Tyagi AK, et al. Endovascular treatment of wide-necked intracranial aneurysms using the novel contour neurovascular system: a single-center safety and feasibility study. J Neurointerv Surg 2020;12:987-92.

3 Aguilar Perez M, AlMatter M, Hellstern V, et al. Use of the pCONus HPC as an adjunct to coil occlusion of acutely ruptured aneurysms: early clinical experience using single antiplatelet therapy. J Neurointerv Surg 2020;12:862-8.

4 Zaidat 00, Hanel RA, Sauvageau EA, et al. Pivotal trial of the Neuroform Atlas stent for treatment of anterior circulation aneurysms: one-year outcomes. Stroke 2020;51:2087-94.

5 Aguilar Pérez M, Hellstern V, AlMatter M. The Medina embolic device - clinical experience in 34 aneurysms from a single center. 14th Congress of The World Federation of Interventional and Therapeutic Neuroradiology, 2017.

6 Bhogal P, Udani S, Cognard C, et al. Endosaccular flow disruption: where are we now? J Neurointerv Surg 2019;11:1024-5.

7 Hendricks BK, Yoon JS, Yaeger K, et al. Wide-neck aneurysms: systematic review of the neurosurgical literature with a focus on definition and clinical implications. J Neurosurg 2020;133:159-65.

8 Sirakov A, Minkin K, Penkov M. Comaneci-assisted coiling as a treatment option for acutely ruptured wide neck cerebral aneurysm: case series of 118 patients. Neurosurgery 2020:87:1148-56.

9 Sirakov S, Sirakov A, Minkin K. Early clinical experience with Cascade: a novel temporary neck bridging device for embolization of intracranial aneurysms. J Neurolntervent Surg 2020;12:303-7.

10 Bhogal P, Wong K, Makalanda H. The Cascade device - in vitro tests to assess coil protrusion into the parent vessel. Interv Neuroradiol 2020;26:494-500. 